\title{
Another pharyngitis mimic: intraoral haematoma of the posterior wall of the pharynx in a patient on warfarin and drug-drug interaction
}

\author{
Yu Watanabe, ${ }^{1}$ Toshikazu Abe, ${ }^{1}$ Yasuharu Tokuda ${ }^{2}$
}

${ }^{1}$ Department of Emergency and Critical Care Medicine, Tsukuba Medical Center Hospital, Tsukuba, Japan ${ }^{2}$ Department of General Medicine, Tokyo Joto Hospital, Tokyo, Japan

\section{Correspondence to}

Dr Toshikazu Abe,

abetoshi1@md.tsukuba.ac.jp

Accepted 23 September 2015

\section{DESCRIPTION}

A 64-year-old Japanese man presented to our hospital, with a 3-day history of painful swelling of the right ankle. A physician prescribed amoxicillin/clavulanate for suspected cellulitis. Two days later, although the ankle swelling was improved, the patient developed a sore throat, sputum and voice change, and revisited our hospital. A diagnosis of pharyngitis was performed by a second physician, who placed the patient on a wait-and-see approach However, he revisited our hospital again the following day. His regular medications were warfarin and aspirin for atrial fibrillation.

On examination, the patient's temperature was $37.1^{\circ} \mathrm{C}$. There was significant submucosal haematoma above the soft and hart plates. Purpura was identified on the right dorsal foot. In laboratory data, haemoglobin was $6.2 \mathrm{~g} / \mathrm{L}$ and prothrombin time-international normalised ratio was 19.95 . The patient was subsequently admitted and the laryngoscopy showed sub-mucosal haematoma from the posterior wall of the pharynx to the piriform recess (figure 1A, B). He received red cell transfusion and vitamin $\mathrm{K}$, without any intervention. On the second day of admission, PT-INR was reduced to 1.8. A second-look laryngoscopy on the seventh day showed that the haematoma had significantly reduced. On the 12th day, the patient was discharged home, without a sequel.

Drug-drug interaction is one of the most common causes for increased warfarin overanticoagulation effects; this is apart from causes related to age, food, alcohol use, poor drug compliance and malignancy. The Ninth ACCP Guidelines on vitamin $\mathrm{K}$ antagonists listed drugs to avoid concomitant treatment with, these include non- steroidal anti-inflammatory drugs, certain antibiotics and antiplatelet agents. ${ }^{1}$ We should consider that over-anticoagulation could also occur in patients with a bacterial infection who take warfarin. We recommend monitoring coagulation in those patients more frequently. There are many grave diseases mimicking pharyngitis, but intraora submucosal haematoma should be considered in patients with a sore throat who are on warfarin.

\section{Learning points}

Potential killer lists of sore throat should include intraoral submucosal haematoma especially in patients on warfarin anticoagulation.

- Haemorrhagic complication due to overanticoagulation from drug-drug interaction should be considered for patients on warfarin who receive a new medication.

Contributors YW examined the patient. YW and TA drafted the manuscript. TA and YT revised the manuscript. All the authors approved the final version of the manuscript.

Competing interests None declared.

Patient consent Obtained.

Provenance and peer review Not commissioned; externally pee reviewed.

\section{REFERENCE}

1 Holbrook A, Pharm D, Schulman S, et al. Evidence-Based Management of Anticoagulant Therapy: Antithrombotic Therapy and Prevention of Thrombosis, 9th ed: American College of Chest Physicians Evidence-Based Clinical Practice Guidelines. Chest 2012;141(Suppl 2):e152S-84S.
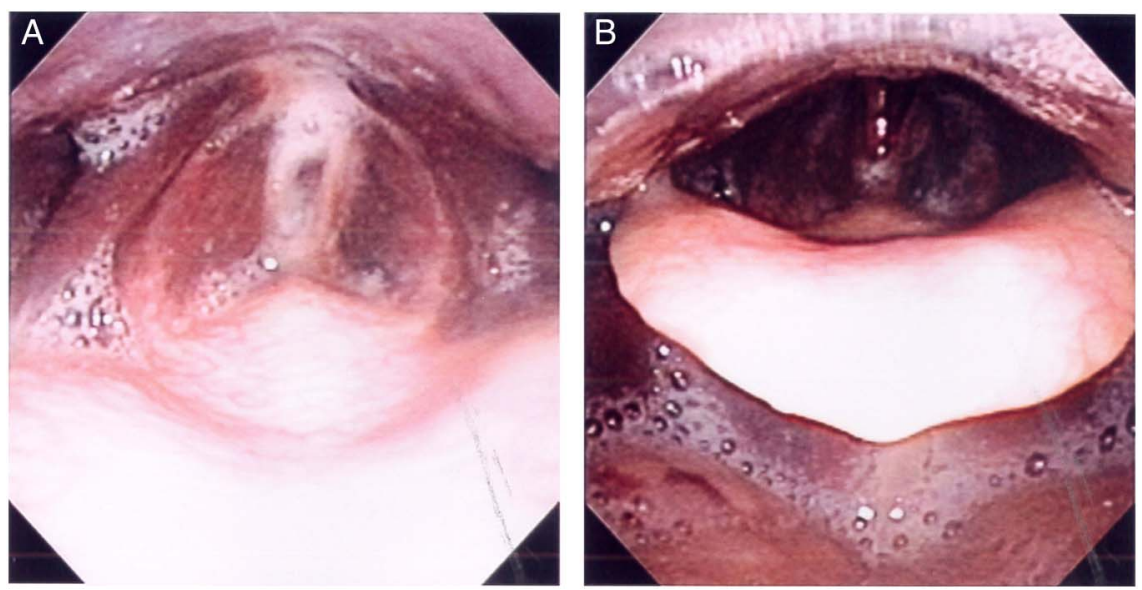

Figure 1 (A and B) Submucosal haematoma from the posterior wall of the pharynx to the pyriform. 
Copyright 2015 BMJ Publishing Group. All rights reserved. For permission to reuse any of this content visit http://group.bmj.com/group/rights-licensing/permissions.

BMJ Case Report Fellows may re-use this article for personal use and teaching without any further permission.

Become a Fellow of BMJ Case Reports today and you can:

- Submit as many cases as you like

- Enjoy fast sympathetic peer review and rapid publication of accepted articles

- Access all the published articles

- Re-use any of the published material for personal use and teaching without further permission

For information on Institutional Fellowships contact consortiasales@bmjgroup.com

Visit casereports.bmj.com for more articles like this and to become a Fellow 